\title{
Tropical Cyclone Eline and Its Unusual Penetration and Impacts over the Southern African Mainland
}

\author{
C. J. C. Reason And A. Keibel \\ Oceanography Department, University of Cape Town, Rondebosch, South Africa
}

(Manuscript received 12 December 2002, in final form 29 March 2004)

\section{ABSTRACT}

\begin{abstract}
February-March 2000 saw devastating floods in Mozambique, Zimbabwe, and South Africa. Due to the huge damage and loss of life, global media attention was extensive. Less well known is that one of the weather systems that contributed to these floods (ex-Tropical Cyclone Eline) tracked almost $2000 \mathrm{~km}$ across southern Africa toward the cool southeast Atlantic and led to substantial rainfall over arid to semiarid southern Namibia (over two standard deviations above average for these two months and the wettest summer since 1976). Less than 5\% of southwest Indian Ocean tropical cyclones actually make landfall on the east coast of southern Africa and even fewer significantly penetrate into the interior, because of the relatively dry 1-1.5-km-high interior plateau that covers most of the region. It is argued that the precursor synoptic conditions together with largescale circulation and SST anomalies over the Indian Ocean associated with a strengthening La Niña were highly favorable for this unusual evolution and track of Eline.

A summary of the accuracy of La Réunion and Met Office forecasts of Tropical Cyclone Eline over the Indian Ocean is given. Over the mainland, almost all countries do not have any NWP capacity, and the challenges and potential solutions for improved forecasting for the region are discussed. It is argued that by keeping informed of current rainfall, vegetation, and soil moisture conditions over southern Africa, as well as evolving climate signals in the tropical oceans, local forecasters could at least be in a state of heightened alert in advance, since these factors significantly influence extreme weather event characteristics in the region.
\end{abstract}

\section{Introduction}

February 2000 will long be remembered for devastating floods in Mozambique, Zimbabwe, and South Africa brought about by Tropical Cyclone (TC) Eline in late February and a tropical depression early in the month. Less known is that ex-Eline tracked about 2000 $\mathrm{km}$ across southern Africa toward the Atlantic (Fig. 1) and contributed significantly to the semidesert region of southern Namibia having its wettest summer since 1976 and the third wettest of the last 50 years. About 25\% of the January-February-March (JFM) 2000 rainfall over southern Namibia resulted from this system; thus, it made a very significant contribution to the seasonal total. Eline was the longest-lived tropical storm observed in the southwest Indian Ocean (SWIO) to date, had an unusually zonal track, and penetrated exceptionally far inland over the interior plateau of southern Africa. Note that less than 5\% of TCs occurring in the SWIO over the last 50 years have actually made landfall on the east coast of southern Africa.

In this study, we investigate the highly unusual evolution of TC Eline and its daughter storm across the

Corresponding author address: Dr. Chris Reason, Dept. of Oceanography, University of Cape Town, Rondebosch 7701, South Africa E-mail: cjr@egs.uct.ac.za
SWIO and southern Africa, highlight the significant impacts over southern Africa, and discuss regional forecasting efforts. Most work on SWIO TCs has been published in government internal reports (e.g., South African Weather Service, Mauritius Meteorological Services), and these are reviewed in van Heerden and Taljaard (1998). With the exception of Jury and Pathack (1991), Jury (1993), and Jury et al. (1999), relatively little work has appeared in the refereed literature. Given the relative lack of work on TCs in the region, it is important to investigate cases like Eline that have large rainfall impacts and unusual evolutions.

Section 2 uses National Centers for Environmental Prediction-National Center for Atmospheric Research (NCEP-NCAR) reanalyses (Kalnay et al. 1996), Meteosat images obtained from the National Oceanic and Atmospheric Administration (NOAA), and synoptic charts from the then South African Weather Bureau (SAWB) to analyze the penetration of Eline into southern Africa. The large-scale influences on the highly unusual track of Eline are considered in section 3, including that of SWIO sea surface temperature (SST) via Reynolds optimally interpolated (OI) (Reynolds and Smith 1994) and Tropical Rainfall Measuring Mission (TRMM) (Kummerow et al. 1998) data. Section 4 discusses regional forecasting of this event. The last section contains the conclusions. 


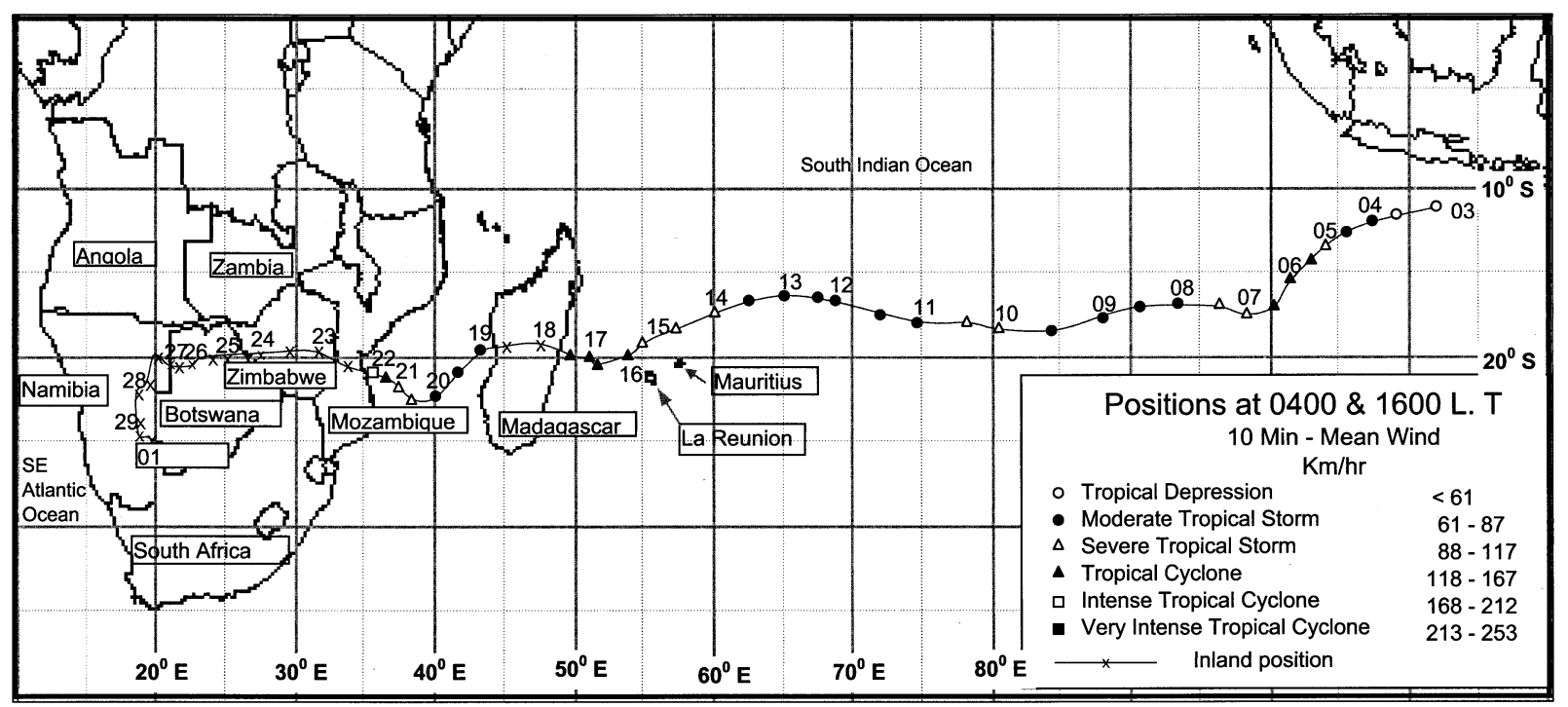

FIG. 1. Track of Eline across the south Indian Ocean and southern African mainland with its position marked at 0400 and 1600 LT during the 3 Feb-1 Mar 2000 period. The wind speeds associated with south Indian Ocean storm categories are given in the legend. The figure is reproduced courtesy of Mauritius Meteorological Services, which renamed the storm Eline after it crossed $90^{\circ} \mathrm{E}$; prior to this it was identified as Tropical Storm Leon.

\section{Synoptic evolution of ex-TC Eline over southern Africa}

TC Eline made landfall in Mozambique at about 0600 UTC 22 February 2000 after tracking over $7000 \mathrm{~km}$ west across the tropical south Indian Ocean (Figs. 1, 2a). Note that Fig. 1 shows the wind speeds associated with south Indian Ocean storm categories. This was Eline's second landfall; it crossed the island of Madagascar on 17/18 February where wind gusts of up to $250 \mathrm{~km} \mathrm{~h}^{-1}$ were recorded on the east coast at Mahanoro. This track was unusual because, typically, TCs in the SWIO tend to track southwest and then recurve southeast, whereas the smaller numbers of TCs that cross into or form in the Mozambique Channel usually move south and then recurve southeast out into the open ocean (e.g., Diab et al. 1991; Jury and Pathack 1991). Although inland penetration is highly unusual, there were in fact three large-scale precursor features in existence over the region that have previously been identified as favoring a westward track of TCs (Olivier 1993). Forecasters could have recognized these at the time as indicating the likelihood of significant impacts of Eline over southern Africa.

First, sea level pressure anomalies to the south of the Mozambique Channel were positive during January and February, indicating increased anticyclonic ridging south of Africa and unfavorable conditions for the southward track of tropical depressions. A strong ridge of high pressure extending to midlevels was in existence across eastern South Africa and the neighboring SWIO throughout 14-24 February (Figs. 2b,d, 3) (i.e., several days before Eline's first landfall in Madagascar) with its maximum spatial extent on 21 and 22 February
(Figs. 3d,e) prior to landfall in Mozambique. Second, a trough aligned northwest-southeast across the southern African interior existed on 21-24 February (Fig. 2 ) and its associated low-level moisture convergence and convection (Figs. 4a,b) helped sustain the landfalling Eline as it tracked farther west (e.g., Jury and Pathack 1991). Third, easterly winds at $500 \mathrm{hPa}$ of about $10 \mathrm{~m} \mathrm{~s}^{-1}$ associated with the northern half of the ridge occurred in the southern Mozambique Channel and neighboring SWIO, and acted as a steering current toward and across southern Africa during 1428 February (Fig. 5).

Late on 22 February, ex-Eline passed the Mozambique/Zimbabwe border some $200 \mathrm{~km}$ inland from the channel (Fig. 1). After crossing the 2000-2500-m-high Chimanimani Mountains in eastern Zimbabwe, ex-Eline weakened from moderate tropical storm to tropical depression status. Convection over Namibia was weaker than a day or so previously as a result of subsidence from the outflow ahead of Eline. During 24-27 February, the storm moved over northeastern Botswana toward Namibia (Figs. 4b-e, 6). Upper-level anticyclonic conditions (not shown) strengthened over the region, thereby facilitating ascent in the lower and middle troposphere and development of ex-Eline. A further favorable feature for the continued development of the storm was cyclonic wind shear present between the 850$\mathrm{hPa}$ (just above the interior plateau of southern Africa) and 700-hPa levels over the region (not shown). Relatively strong midlevel easterlies (Figs. 5f-h) existed over the region from Botswana east to the SWIO during 24-29 February, thereby continuing to steer the storm westward to Namibia. 


\section{$\underline{22 \text { February } 2000}$}

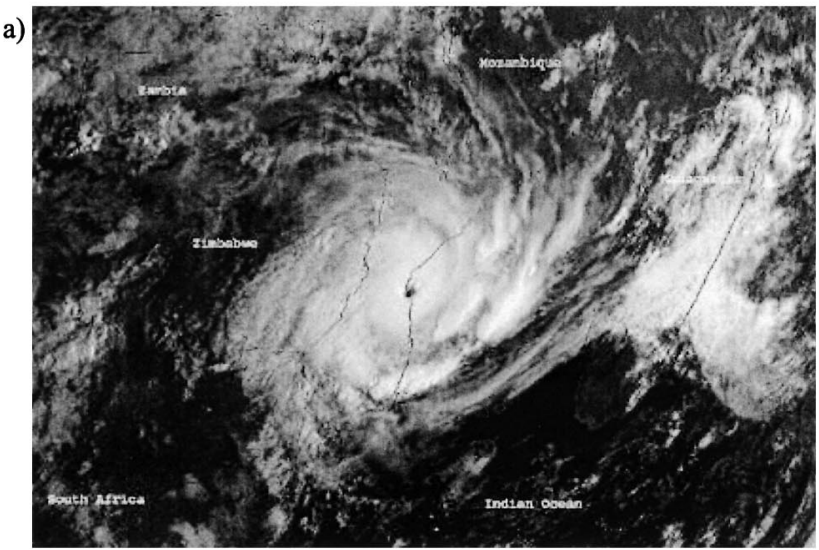

b)

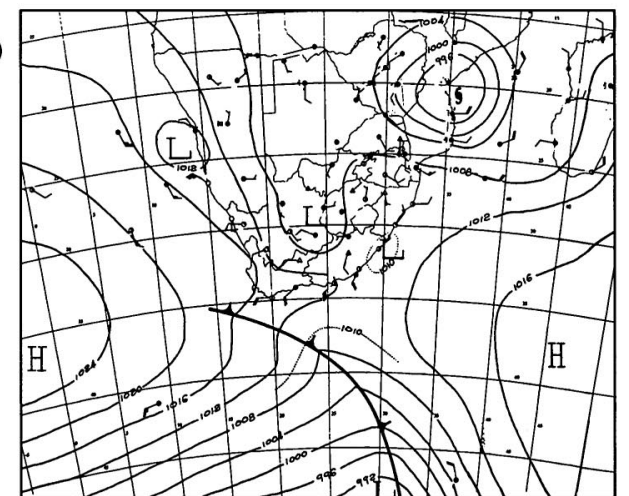

$\underline{23 \text { February } 2000}$

c)

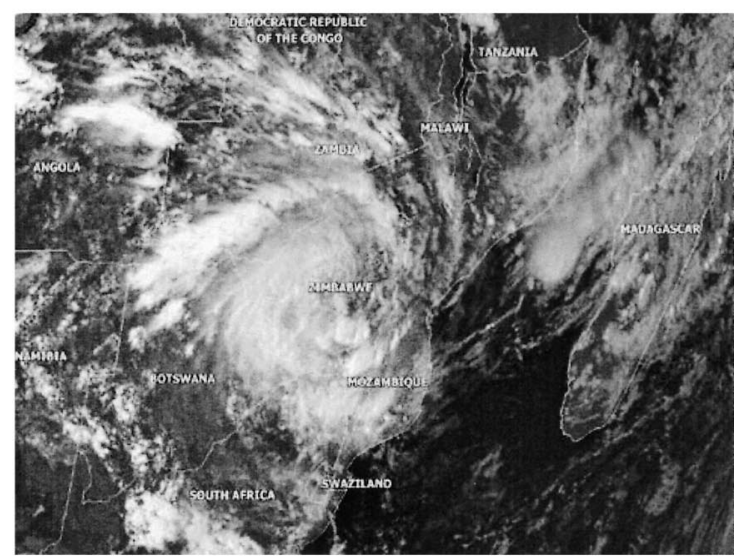

d)

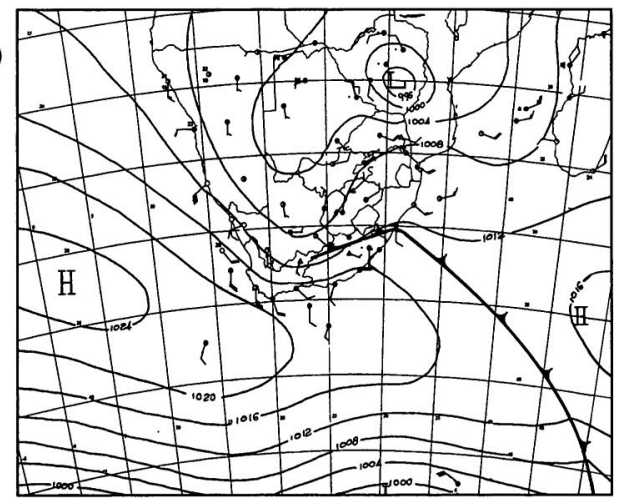

FIG. 2. (a) Meteosat infrared satellite image (obtained from NOAA) for 0630 UTC 22 Feb; (b) SAWB synoptic chart for 1200 UTC 22 Feb; (c) Meteosat infrared satellite image (obtained from NOAA) for 0630 UTC 23 Feb; (d) SAWB synoptic chart for 1200 UTC 23 Feb.

At the same time, the anticyclone in the SWIO strengthened, leading to northeasterly flow of moist air at low levels over eastern South Africa and further development of the heat low to the south (Figs. 4b-g, $6 \mathrm{~b}, \mathrm{~d})$. Northern Namibia received significant rainfall (regional average over $10 \mathrm{~mm}$ ) on 27 February (Fig. $4 \mathrm{e}$ ), and this continued the next day (Fig. 6c) as exEline and the heat low merged into a large trough extending across Namibia down to the South African coast (Fig. 6d).

This tropical trough evolved ahead of a cold front approaching the far southwest coast from the South Atlantic, and these two systems formed a tropical-extratropical cloud band on 29 February and 1 March (Fig. 7) stretching northwest-southeast across southern Africa. The associated convection over southern Namibia on 29 February produced the greatest daily falls of the entire summer (40-60 $\mathrm{mm}$ at several stations). About 25-40 mm fell over southeastern Namibia on 1 March as the convective activity began to shift eastward with the westerly migration of the cloud band and the subsequent ridging of the next South Atlantic anticyclone behind the front. This marked the end of wet conditions over southern Namibia until the third and final significant rainfall event of summer 1999/2000 about a month later.

Figure 8 shows moisture fluxes and associated convergence at $850 \mathrm{hPa}$ for the 3 pentads (5-day average) up to and including the significant rainfall event of 29 February. Pentads are used to focus on the moisture flux during the evolution of the event and to remove diurnal convective effects. During 16-20 February, when southern Namibia had its first major wet spell of the season, the low-level moisture flux (Fig. 8a) looks similar over southern Africa to the summer climatology except that there was enhanced convergence over northern Namibia-southeastern Angola. Also, there was increased moisture flux into eastern Namibia from the SWIO where Eline itself is evident. During 21-25 February, the lowlevel flux over southern Africa was dominated by the circulation associated with ex-Eline (Fig. 8b), and southern Namibia was relatively dry. The 26 February1 March pentad (Fig. 8c) corresponds to the second major wet spell of the summer over southern Namibia, 
(a)

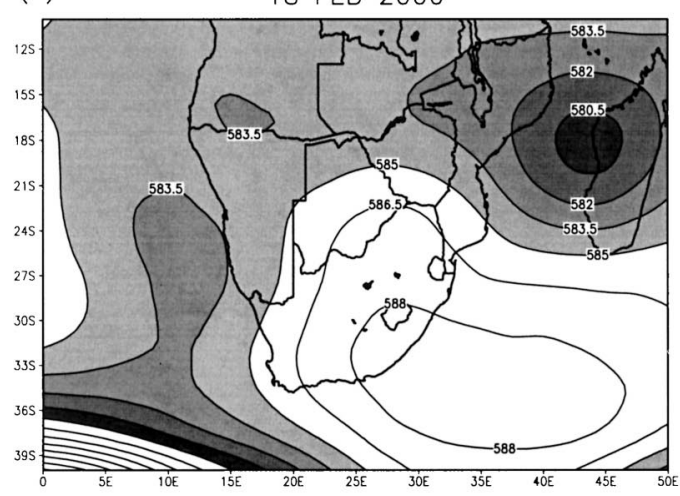

(c)

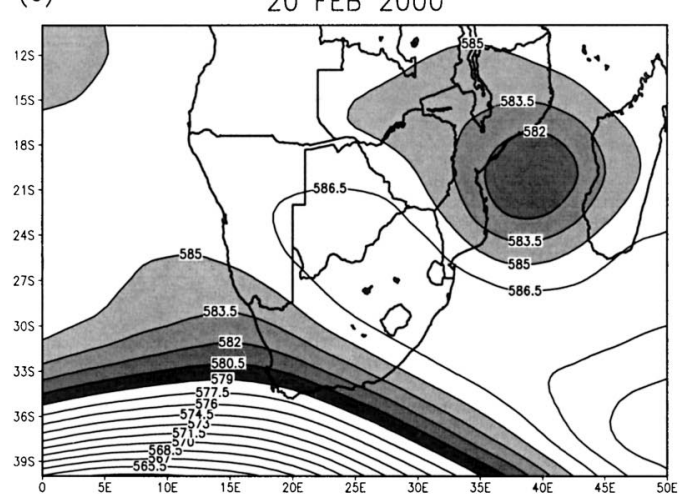

(e)

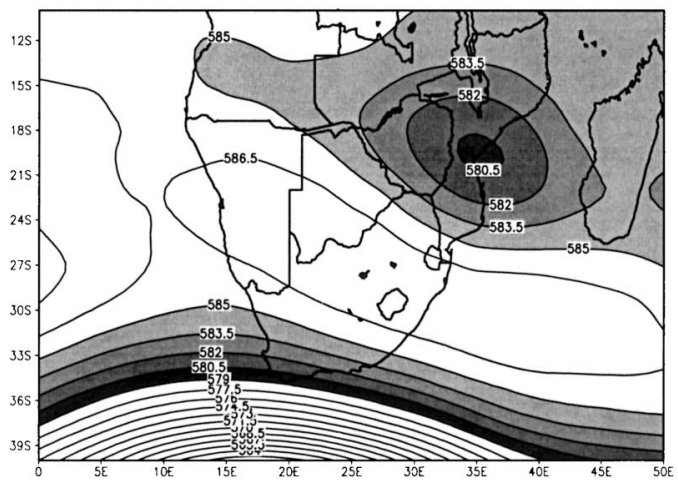

(b)

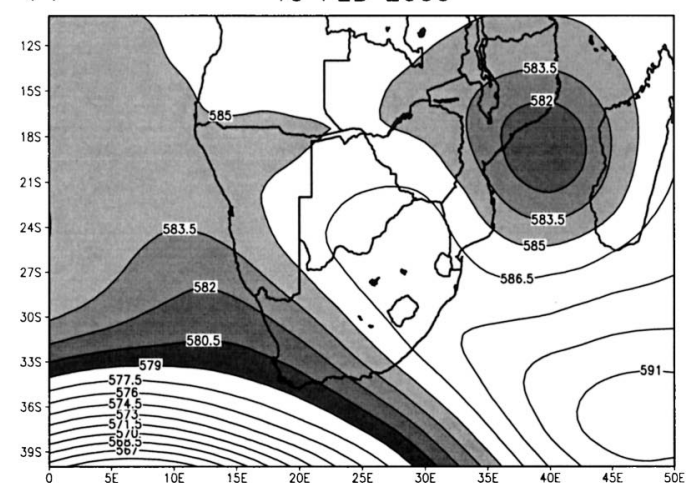

(d)

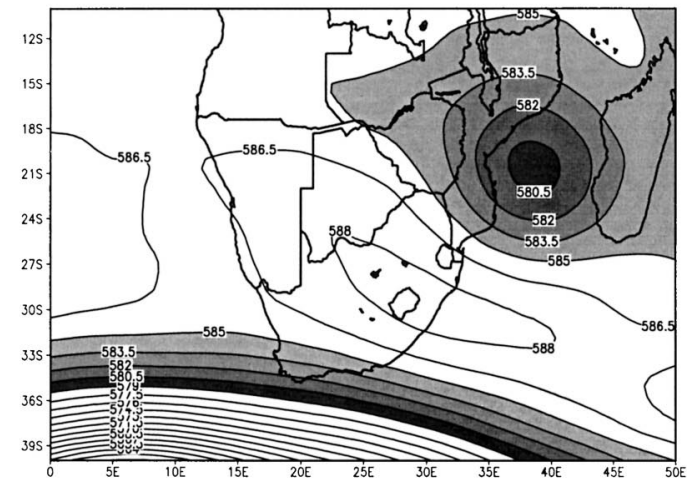

(f)

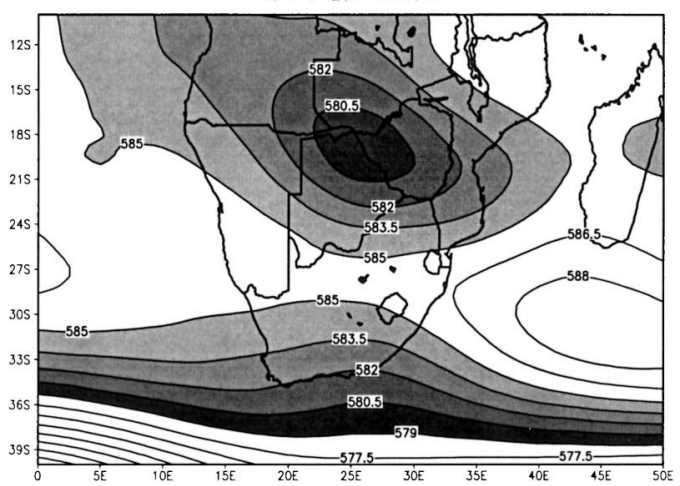

FIG. 3. (a)-(f) Daily averaged geopotential height (contour interval $1.5 \mathrm{dam}$ ) at the 500-hPa level from NCEP reanalyses for 18-24 Feb. Shading denotes values in the range 579-585 dam so as to highlight Tropical Cyclone Eline.

including its wettest day (29 February), and shows some similarities in moisture flux with pentad 1 over the mainland. The cyclonic feature over northern Namibiasouthern Angola is more focused and slightly stronger than that for pentad 1, with increased flux from the SWIO compared to the mean flow. Like pentad 1, the cyclonic feature is not only intensified relative to the mean but also shifted south over Namibia, reflecting the presence of ex-Eline itself. The significant inflow of moisture from the subtropical SWIO and, to lesser extent, the tropical southeast Atlantic Ocean then combined with the trough in the westerlies south of Africa to promote the cloud band that occurred over southwestern Africa during 29 February-1 March. 
(a)

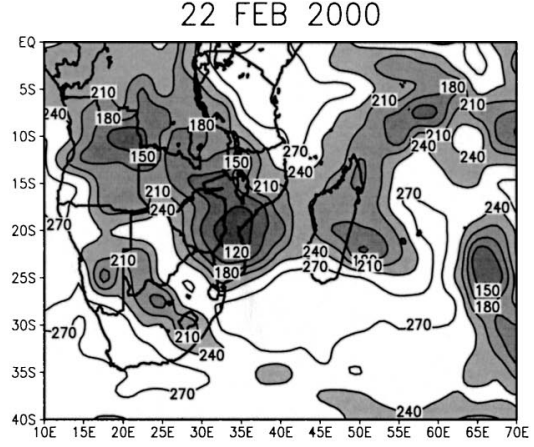

(c)

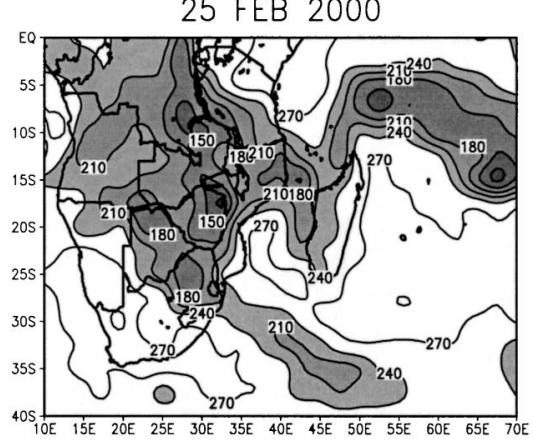

27 FEB 2000

(e)

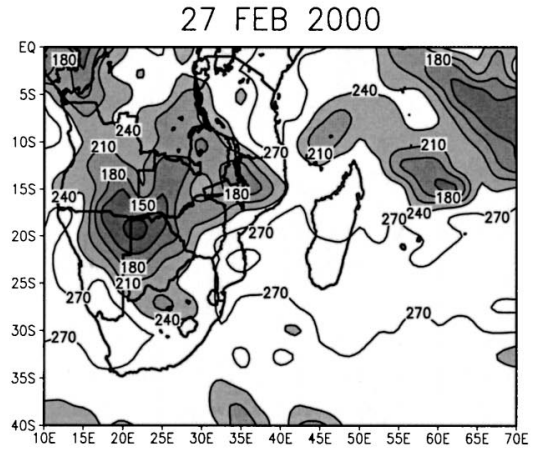

(g)

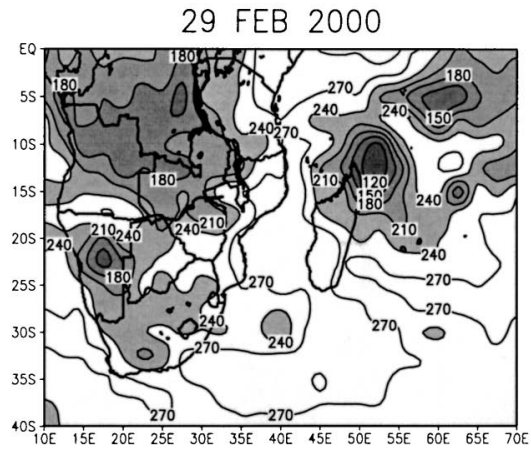

(b)

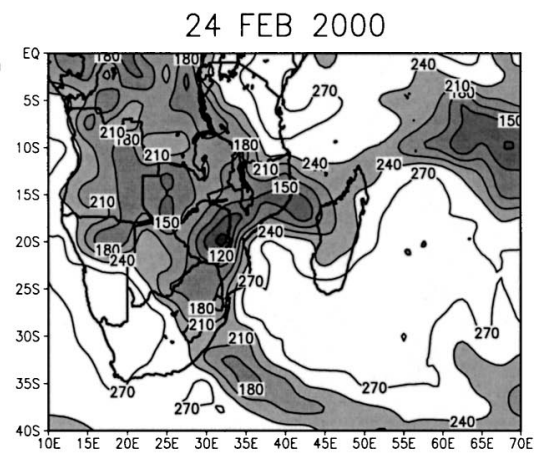

(d)

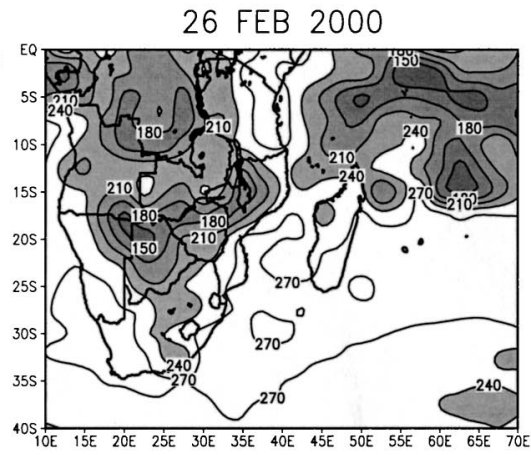

(f)

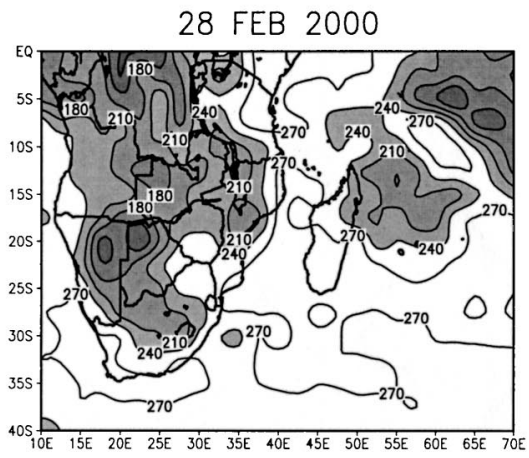

1 MAR 2000

(h)

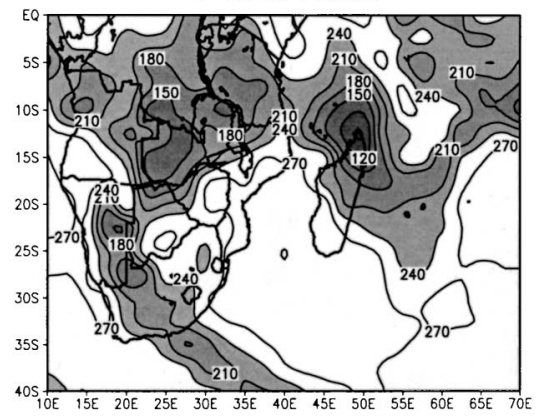

FIG. 4. (a)-(h) Daily interpolated outgoing longwave radiation (contour interval $30 \mathrm{~W} \mathrm{~m}^{-2}$ ) from NCEP-NCAR for various days between $22 \mathrm{Feb}$ and 1 Mar. Shading denotes values less than or equal to $240 \mathrm{~W} \mathrm{~m}^{-2}$ or areas where convection is likely. 
18 FEB 2000

(a)

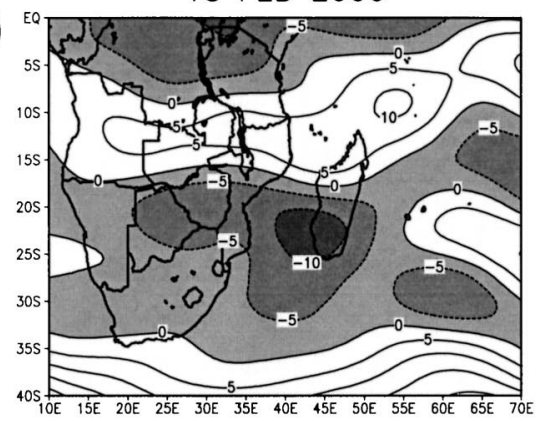

(c)

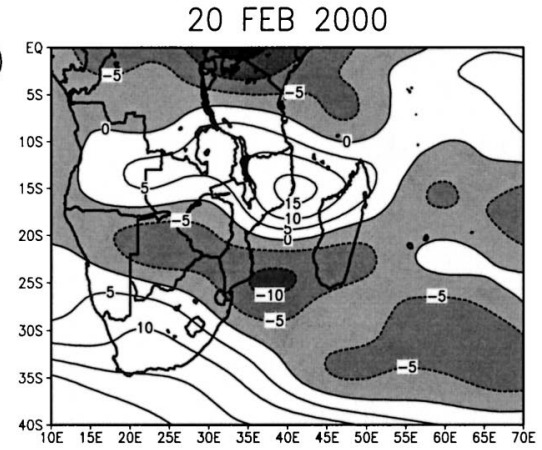

23 FEB 2000

(e)

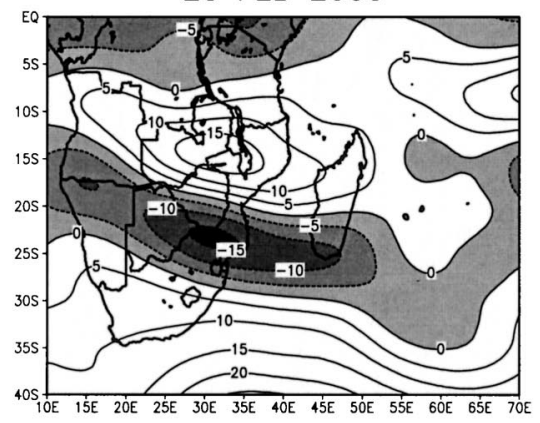

(g)

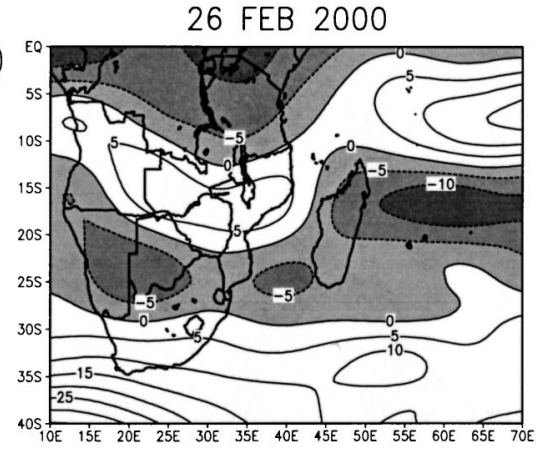

19 FEB 2000

(b)

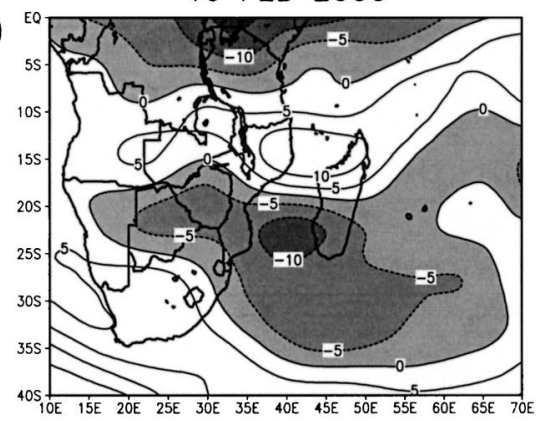

22 FEB 2000

(d)

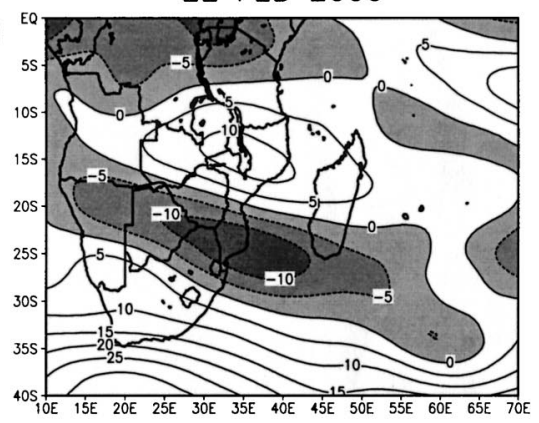

24 FEB 2000

( $f$ )

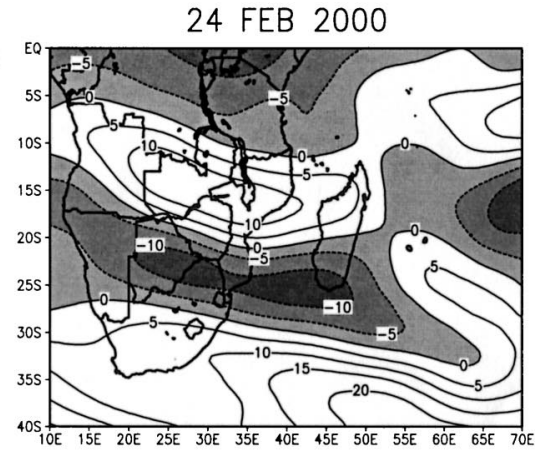

(h)

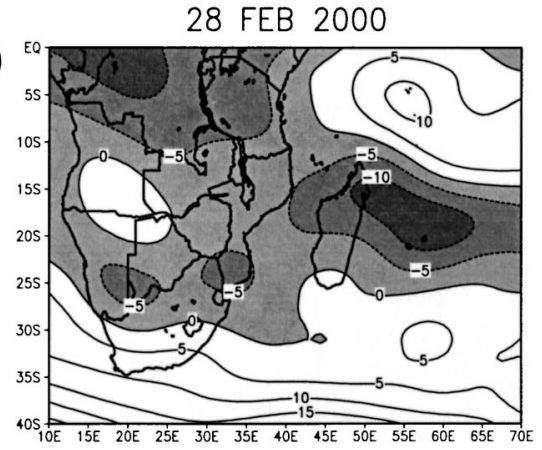

FIG. 5. (a)-(h) Zonal wind (contour interval $5 \mathrm{~m} \mathrm{~s}^{-1}$ ) at the 500-hPa level from NCEP reanalyses for various days during 18-28 Feb. Easterly winds (westward steering current) are shaded. 


\section{$\underline{25 \text { February } 2000}$}

a)

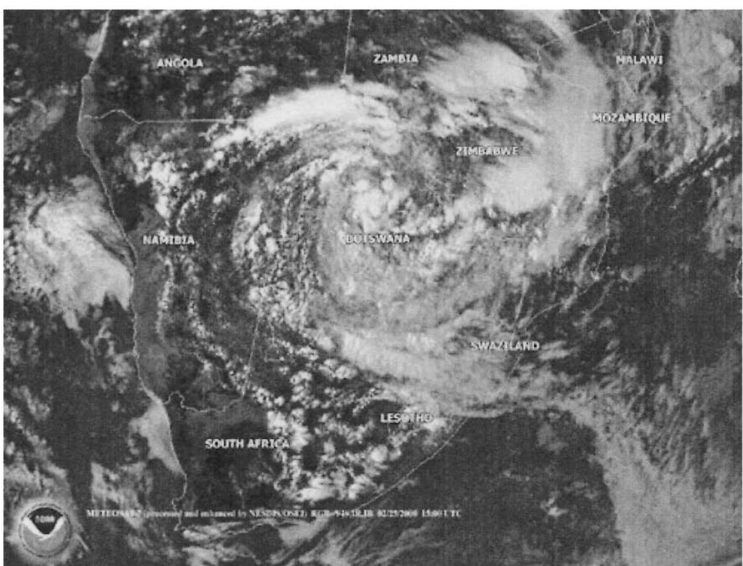

b)

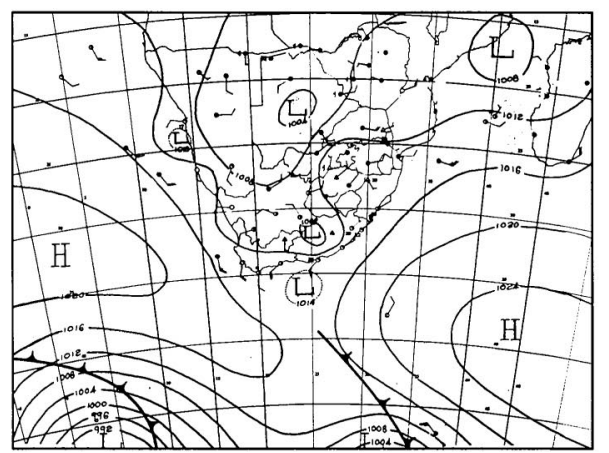

$\underline{28 \text { February } 2000}$

c)

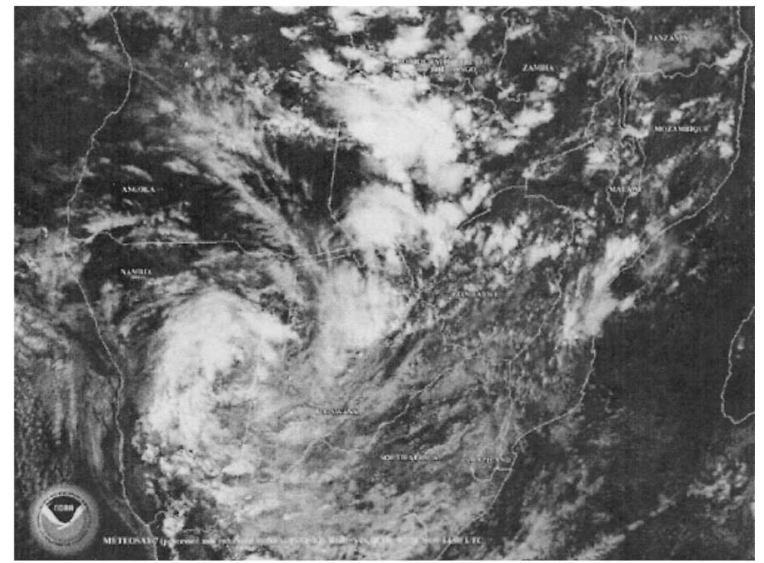

d)

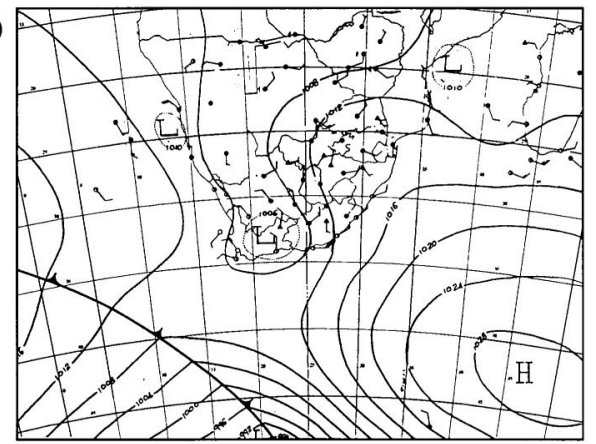

FIG. 6. (a) Meteosat infrared satellite image (obtained from NOAA) for 1500 UTC 25 Feb; (b) SAWB synoptic chart for 1200 UTC 25 Feb; (c) Meteosat infrared satellite image (obtained from NOAA) for 1400 UTC 28 Feb; (d) SAWB synoptic chart for 1200 UTC 28 Feb.

\section{Large-scale influences on Eline's track}

In this section, we consider the question as to whether the large-scale climatic and ocean conditions during austral summer 2000 also helped promote Eline's anomalous evolution. In particular, we focus on possible influences from the prolonged 1998-2001 La Niña on the evolution of TC Eline.

\section{a. ENSO and regional ocean influences}

During El Niño, TC tracks tend to concentrate in the $50^{\circ}-70^{\circ} \mathrm{E}$ band just east of Madagascar since the high pressure anomalies centered over the eastern Indian/ Australasian sector are unfavorable for TCs farther east. During La Niña, TC tracks in the tropical south Indian Ocean are relatively spread out, with more occurring in the Mozambique Channel. Vitart et al. (2003) used NCEP reanalyses and an AGCM forced with prescribed SST to find that SWIO TCs show a more zonal track during La Niña years, which significantly increases the chance of TC landfall in Mozambique. If a westward steering current existed, then warm SSTs in the SWIO were found by these authors to further promote landfall.
La Niña conditions strengthened again during early 2000 after a lull in mid-1999 and warm SST anomalies evolved near Mozambique (Fig. 9), favoring local intensification and landfall of tropical systems. Reynolds optimally interpolated SST and TRMM SST data both indicate that during the week prior to Eline, SST in the Mozambique Channel was somewhat warmer $\left(29^{\circ}-\right.$ $30^{\circ} \mathrm{C}$ ) than that east of Madagascar (about $28^{\circ} \mathrm{C}$ ) in the latitude band corresponding to its track (Fig. 9). In fact, the westward track of Eline across the Mozambique Channel corresponded to the tongue of warmest SST between Madagascar and the mainland evident in Fig. 9a, and these SSTs were above average for both January and February (Figs. 9b,c). TRMM data suggests that this tongue was even warmer than that shown in Fig. $9 \mathrm{a}$, and maxima of $31^{\circ}-32^{\circ} \mathrm{C}$ occurred in the eastern part of the channel. Hence, Eline regained tropical cyclone status on 21 February when it was located about $80 \%$ of the way across the channel (Fig. 1) and then strengthened further to intense tropical cyclone status on 22 February over the western margins of the channel just prior to landfall.

SSTs in the tropical southeast Indian Ocean near 


\section{February 2000}

a)

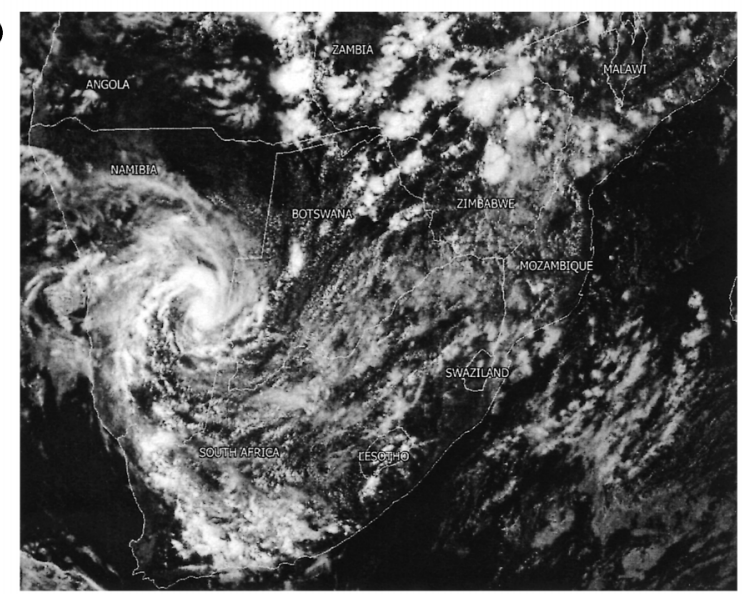

b)

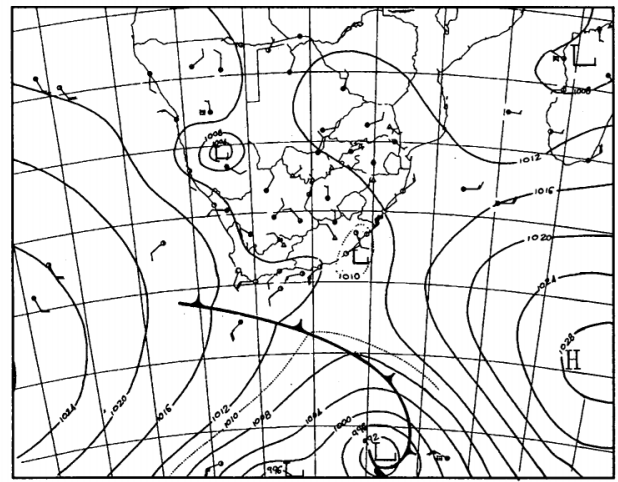

c)

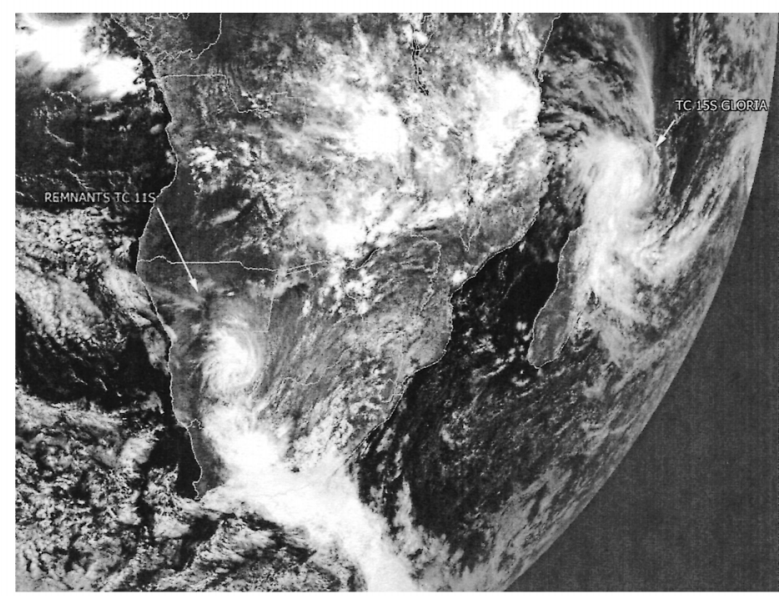

d)

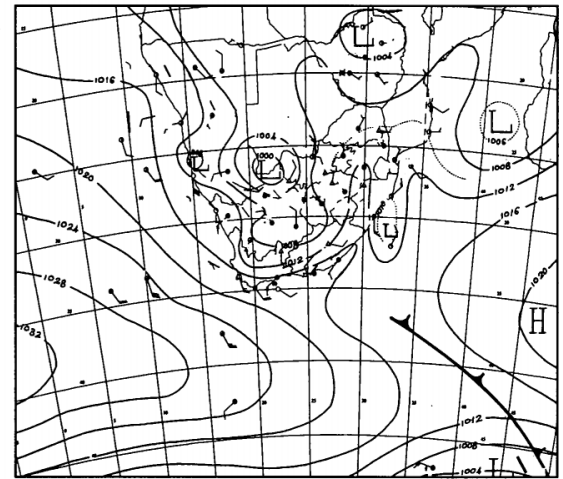

FIG. 7. (a) Meteosat infrared satellite image (obtained from NOAA) for 1400 UTC 29 Feb; (b) SAWB synoptic chart for 1200 UTC 29 Feb; (c) Meteosat infrared satellite image (obtained from NOAA) for 1200 UTC 1 Mar; (d) SAWB synoptic chart for 1200 UTC 1 Mar.

where Eline was generated were $0.5^{\circ}-2^{\circ} \mathrm{C}$ above average (Figs. 9b,c) in January and February, favoring storm genesis. Waters immediately southeast of Madagascar were $0.5^{\circ}-2^{\circ} \mathrm{C}$ cooler than average during both months (Figs. 9b,c), discouraging a track farther south into the SWIO as is usual. Figures 1 and 9a suggest that Eline's westward track along about $17^{\circ} \mathrm{S}$ during 7-17 February followed the $28^{\circ} \mathrm{C}$ surface isotherm. Other south Indian Ocean TCs have tended to track on, or just north of, this isotherm (Jury 1993). During January and February 2000 , this isotherm was more zonal in orientation across the south Indian Ocean, yet another important aspect of the SST field in early summer 2000 that influenced Eline's track westward into the southern African mainland.

Xie et al. (2002) argued that the highest TC occurrence in the SWIO is located near the region of climatological minimum in thermocline depth, where correlations of this depth with SST are greatest. These authors present evidence that years with deeper-than-average thermocline depth in the $8^{\circ}-12^{\circ} \mathrm{S}, 50^{\circ}-70^{\circ} \mathrm{E}$ region tend to have more TC in the SWIO than those with shallower thermocline depths. To see whether this suggested relationship might also hold true for Eline, plots of subsurface ocean temperature were constructed from Estimating the Circulation and Climate of the Ocean (ECCO) model analyses (Stammer et al. 2003). Although Eline occurred farther south $\left(17^{\circ}-18^{\circ} \mathrm{S}\right)$, these plots indicate (not shown) that over $8^{\circ}-12^{\circ} \mathrm{S}, 50^{\circ}-70^{\circ} \mathrm{E}$, the thermocline was indeed deeper than the model climatology during January and early February 2000. Further research is needed, but this suggests that improved TC predictability could result if a (Tropical Atmosphere Ocean) TAO-type monitoring array is established in the tropical SWIO.

\section{b. Large-scale atmospheric circulation anomalies}

Large-scale circulation patterns are also fundamental for influencing TC evolution. At $200 \mathrm{hPa}$ (not shown), positive anomalies and divergence existed over the eastern/central tropical south Indian Ocean during the 2 weeks before Eline reached $90^{\circ} \mathrm{E}$ on 8 February. Midto low-level negative (positive) geopotential height anomalies (Fig. 10) were also present in the tropical (subtropical and midlatitude) south Indian Ocean. These pressure anomalies and the resulting enhanced easterlies or westward steering flow along $15^{\circ}-25^{\circ} \mathrm{S}$ and cyclonic 
shear equatorward of this zonal band were, together with the SST conditions, very conducive for the generation and subsequent westward track of Eline. The importance of this steering flow for enhancing the risk of SWIO TC making landfall on Mozambique is consistent with climatology and AGCM experiments (Vitart et al. 2003).

\section{c. Potential land surface influences}

Large areas of southern Africa received one to two standard deviations above average rainfall in December 1999 and January 2000. These areas included the track of ex-TC Eline across southern Africa, implying that the precursor surface conditions over the land were considerably moister than average. NCEP reanalyses indicate that most of central and western southern Africa had significant positive soil moisture anomalies in December 1999, and these wetter soil conditions intensified further in January 2000. Normalized Difference Vegetation Index (NDVI) images (Anyamba et al. 2002) show positive anomalies of $30 \%-100 \%$ across much of southern Africa in December 1999 and January 2000, indicating that the vegetation was substantially greener than average. The enhanced vegetation and soil moisture over much of southern Africa implies increased latent heat flux into the atmosphere, which is conducive to local intensification of weather systems.

Figures 11a and 11b suggest that there was considerably enhanced latent heat flux into the lower atmosphere over much of southern Africa during the 2 months prior to Eline. During the 10 days prior to Eline approaching Mozambique, there was increased flux right across the subsequent track region over southern Africa and the SWIO (Fig. 11c). In fact, Eline seems to have followed the $+60 \mathrm{~W} \mathrm{~m}^{-2}$ anomaly contour seen to extend from $80^{\circ} \mathrm{E}$ to Madagascar in Fig. 11c. Thus, conditions over the landmass were, together with those of the south Indian Ocean, very favorable for Eline's intensification near Mozambique and penetration 2000 $\mathrm{km}$ inland.

\section{d. Summary}

Compared to composite maps of 10 strong La Niña events over the past century (Reason et al. 2000), the January and February 2000 anomalies show stronger subtropical high pressure in the SWIO, further enhancing the already favorable La Niña westward steering flow toward Mozambique. SST anomalies during early 2000 were similar to the composite with the important exception of warm SST anomalies in both the Mozambique Channel and north and northeast of Madagascar (Figs. 9b,c) where the composite displays cool anomalies. Furthermore, the La Niña-induced atmospheric circulation anomalies represented a persistent pattern during late 1999 and early 2000, leading to wetter soils and an anomalously high green vegetation fraction, thereby contributing to maintenance of Eline after land- fall. Two (Danae, Filao) of the four other ex-TCs in the last 50 years that have tracked unusually far west into southern Africa also occurred during La Niña years (1976, 1988), and in both cases, warm SST anomalies near Mozambique and pronounced SWIO high pressure anomalies led to a strong westward steering current, favoring penetration. This evidence indicates that local forecasters should keep informed of local land surface and SST conditions as well as current La Niña state, given the evidence of their influence on inland penetration of SWIO TCs.

\section{Regional forecasting of Eline}

The Tropical Cyclone Regional Specialised Meteorological Centre (RSMC) with World Meteorological Organisation (WMO) forecasting responsibility for the SWIO $\left(5^{\circ}-30^{\circ} \mathrm{S}, 90^{\circ} \mathrm{E}\right.$ to the southern African mainland) is La Réunion (Météo France). This section summarizes the forecasts issued by this RSMC and by Mauritius and discusses the NWP models used. The main tool used by La Réunion is an integrated software system (SYNERGIE) that allows the forecaster to build a conceptual model of the real and future state of the atmosphere by overlaying all available observations, radar and satellite imagery, objective analyses and NWP products. Mauritius uses NWP products obtained from the U.K. Met Office (UKMO) and Méteo France as well as persistence, climatology, and SST observations. Each southern African country has its own meteorological service but only the South African Weather Service runs a regional NWP model (Eta). Weather forecasting elsewhere in southern Africa tends to rely on European Centre for Medium-Range Forecasts (ECMWF) or UKMO products combined with manual analyses based on any available local station data, and these forecasts are not archived. This precludes detailed assessment for these countries; however, where possible, comments about local forecasts are made.

As Eline approached on 14 February, Mauritius Meteorological Services issued increasing levels of warning, with a class III cyclone warning at 1245 local time (LT) when Eline was $350 \mathrm{~km}$ to the northeast (Fig. 1). This warning remained in effect until the morning of 15 February. Given the continuing westward track and advice that there was no longer danger of wind gusts exceeding $120 \mathrm{~km} \mathrm{~h}^{-1}$, a "no warning" signal was issued at 0930 LT that day; however, the bulletin stressed that strong gusts up to $100 \mathrm{~km} \mathrm{~h}^{-1}$ and heavy rains would persist for some time. In fact, the strongest recorded gust (137 $\mathrm{km} \mathrm{h}^{-1}$ ) occurred in northwest Mauritius a few hours later at noon LT. Two other stations also recorded wind gusts over $100 \mathrm{~km} \mathrm{~h}^{-1}$ during the late morning of February 15 after the "no warning" signal had been issued. 
(a) $16-20$ FEB 2000

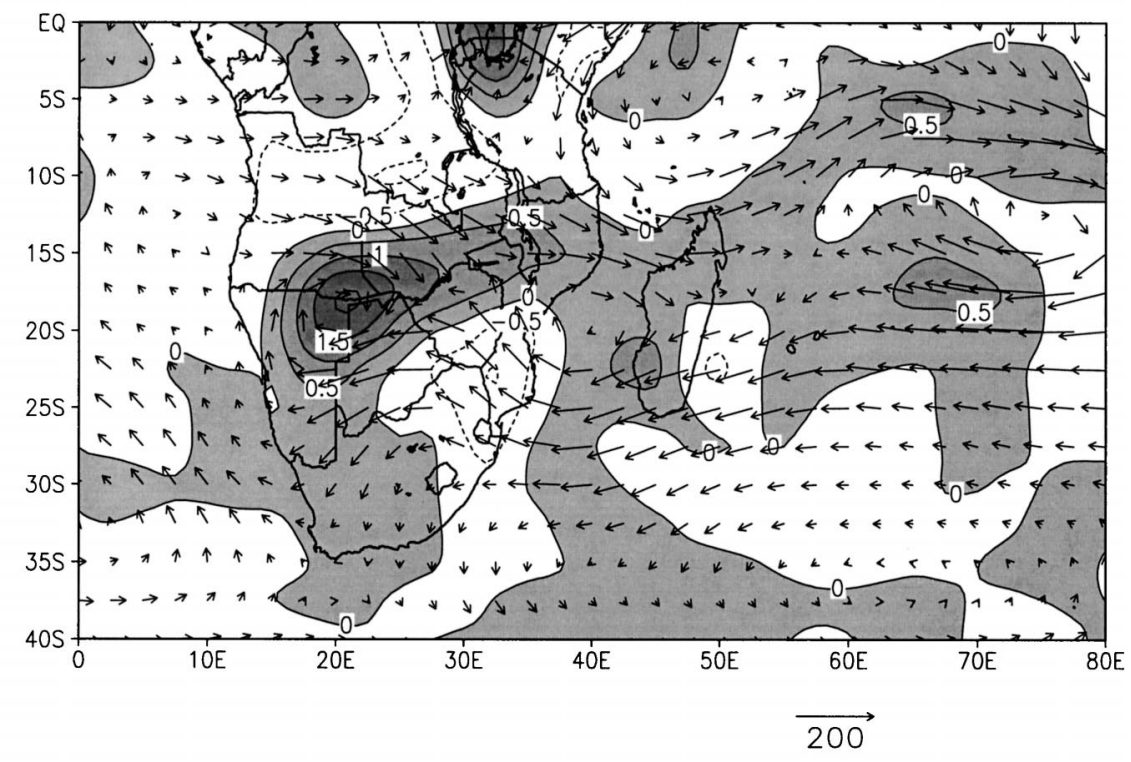

(b) $21-25$ FEB 2000

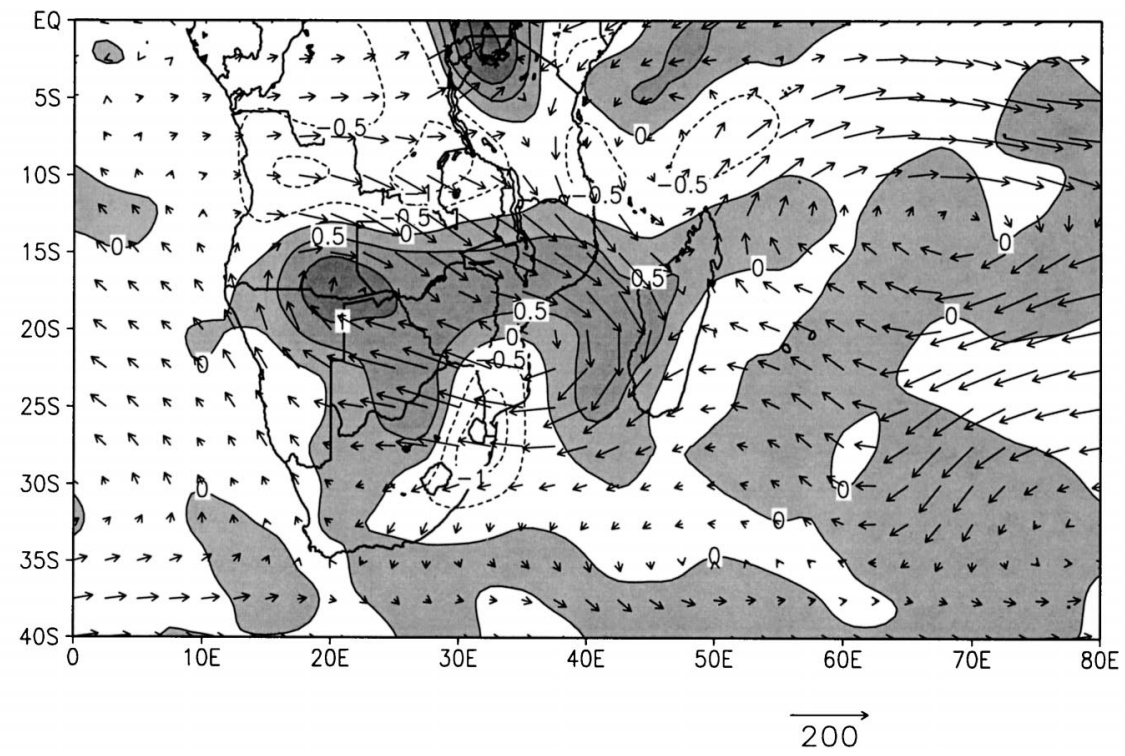

FIG. 8. Moisture fluxes at the $850-\mathrm{hPa}$ level during the following pentads: (a) 16-20 Feb, (b) 21-25 Feb, (c) $26 \mathrm{Feb}-1 \mathrm{Mar} 2000$. A scale vector of $200 \mathrm{~g} \mathrm{~kg}^{-1} \mathrm{~m} \mathrm{~s}^{-1}$ is shown. Contours show moisture convergence (shaded) or divergence (dashed) with an interval of $0.5 \mathrm{~g} \mathrm{~kg}^{-1} \mathrm{~s}^{-1}$.

\section{a. Forecasts issued by RSMC La Réunion}

At 1200 UTC 16 February, La Réunion issued a hurricane warning as Eline neared Madagascar and predicted weakening of the system over the next 12-24 h. Six hours later the forecast indicated that Eline would make landfall on the east coast of Madagascar within 24 h, ending 1800 UTC 18 February, and would dissipate by 1200 UTC 18 February. This scenario was adjusted in three subsequent forecasts issued between
0000 and 1200 UTC 17 February, which correctly predicted a slight intensification and more northwestward track to the system. Although there were some errors in the predicted speed and intensity of Eline, La Réunion forecasts were generally quite accurate regarding track and landfall position. Together with the hurricane warnings issued on 16-17 February, they helped in reducing damage to eastern Madagascar as Eline crossed the country on 17-18 February.

The track forecasts from La Réunion remained quite 


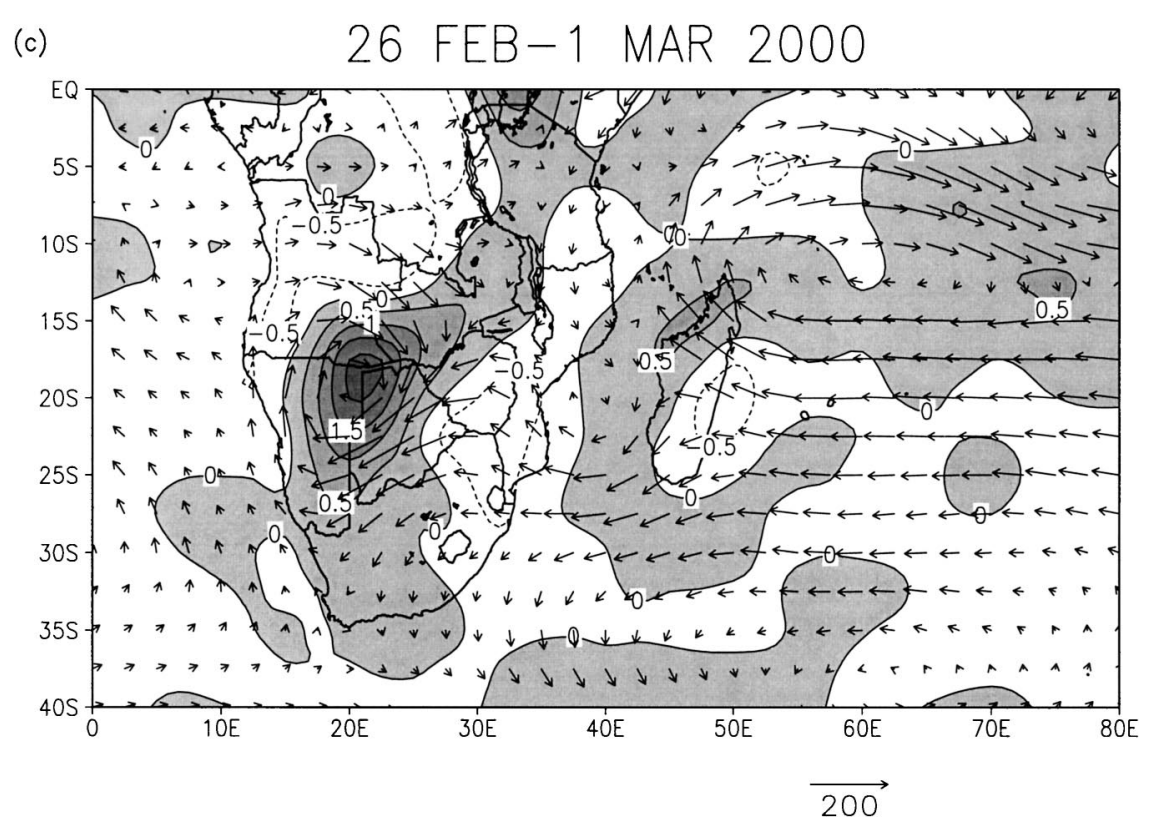

FIG. 8. (Continued)

good during the 3 days that Eline was in the Mozambique Channel. However, the intensity of the system was underforecast during this period, and the forward track speed was overforecast. For example, the 1200 UTC 20 February bulletin forecast slight intensification during the next $12 \mathrm{~h}$ and landfall by 1200 UTC 21 Februaryactual landfall was $42 \mathrm{~h}$ later at about 0600 UTC 22 February. At 0600 UTC 21 February, a storm warning was issued along with advice that Eline might intensify steadily during the next day. In fact, rapid strengthening occurred during the next $6 \mathrm{~h}$, prompting a hurricane warning to be issued at 1200 UTC with expected landfall within the next $12-24 \mathrm{~h}$. Six hours prior to landfall, Eline became an intense tropical cyclone just $45 \mathrm{~km}$ from the Mozambique coast.

At 0600 UTC 22 February, the bulletin noted that the eye was on the Mozambique coast and forecast that Eline would track into Zimbabwe within 36-48 h. Instead, the system moved considerably faster than expected and reached eastern Zimbabwe within 12-18 h. The next three forecasts issued between 1200 UTC 22 February and 0000 UTC 23 February predicted a more rapid weakening of ex-Eline than was observed. The latter forecast issued a gale warning for Zimbabwe, when in fact ex-Eline maintained intensity as a moderate tropical storm (winds exceeding $61 \mathrm{~km} \mathrm{~h}^{-1}$ ) and had tracked farther west than expected. By 1200 UTC 23 February the storm was centered near $30^{\circ} \mathrm{E}$, with severe flooding resulting in southeastern Zimbabwe. Despite advice from forecasters, it appears that an official storm warning was not issued by the Zimbabwean government until after ex-Eline had already impacted the eastern regions of the country. This delay further aggravated the effects of this extreme event.
La Réunion issued storm and gale warnings well after the storm had tracked inland from the coast and out of their area of responsibility; these were used by the Mozambique and South African forecast offices, which issued warnings during 22-25 February.

\section{b. Numerical model track verification}

Both La Réunion (RSMC La Réunion 2002) and the UKMO (Heming 1994, 2001) provide basic information about forecast errors. Since there is a lack of aircraft and other data, monitoring of TCs in the region is essentially based on satellite imagery. The move in June 1998 of Meteosat-5 to above $63^{\circ} \mathrm{E}$ instead of $0^{\circ}$ has been of great benefit for TC monitoring since INSAT data were not available to the RSMC and, until it occurred, the SWIO was the only TC basin in the world without geostationary satellite coverage. Other satellite products, available to La Réunion after the 1998/99 season, are from research-type platforms (Special Sensor Microwave Imager, Tropical Rainfall Measurement Mission, Advanced Microwave Sounding Unit) and have led to improvements in TC forecast accuracy (RSMC La Réunion 2002). When in range, La Réunion or Mauritius radar data are also used.

La Réunion uses the ECMWF IFS model and the French ARPEGE model, for which a version with approximately $40-\mathrm{km}$ uniform resolution has been fitted to oceanic tropical regions. The UKMO global forecast model at the time of Eline had a resolution of $0.83^{\circ} \times$ $0.55^{\circ} \times 30$ levels, or about $90 \mathrm{~km}$ by $60 \mathrm{~km}$ horizontal resolution at the equator. A local maximum of relative vorticity at $850 \mathrm{hPa}$ is used to identify the center of the $\mathrm{TC}$ in the model with a surface fitting technique to locate 
(a)

$$
30 \text { Jan-6 Feb } 2000
$$

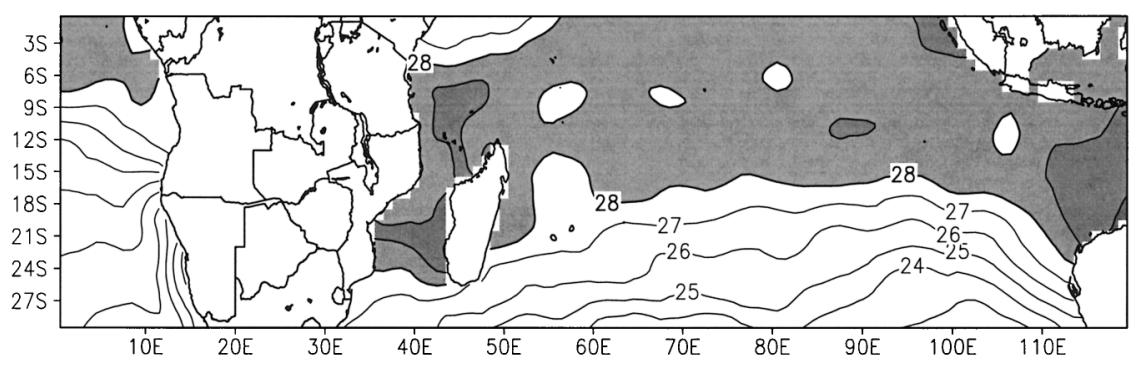

(b)

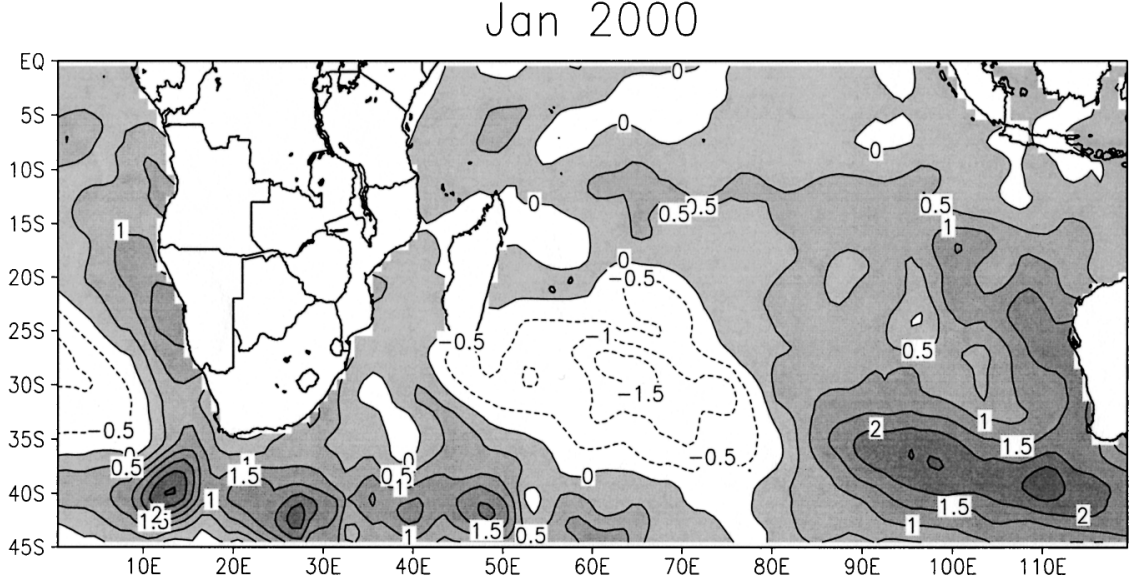

(c)

Feb 2000

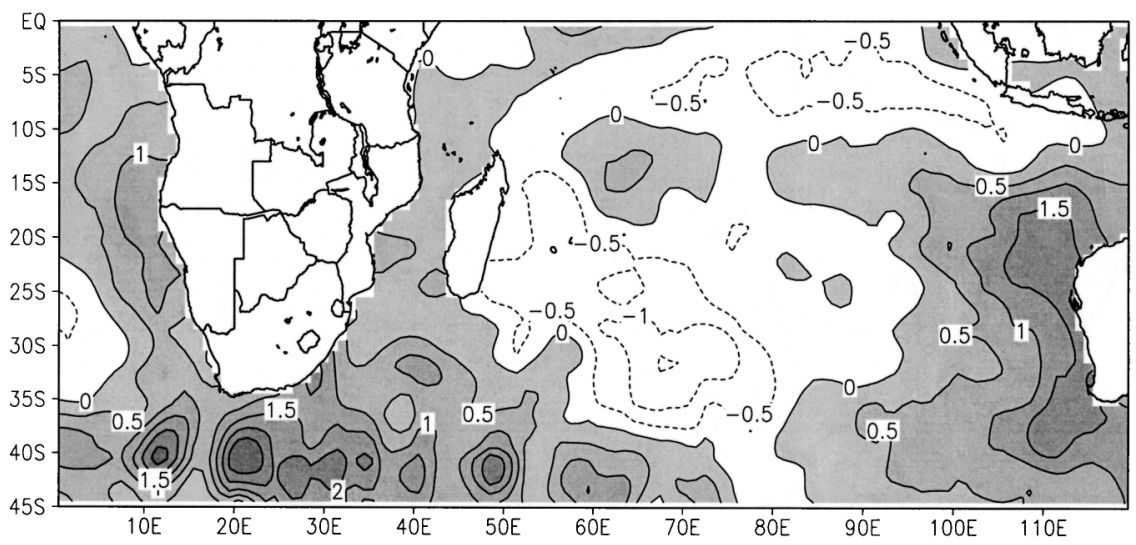

FIG. 9. (a) Sea surface temperature (SST) during the week prior to the generation of Eline. Contour interval $1{ }^{\circ} \mathrm{C}$ with SST above $28^{\circ} \mathrm{C}$ shaded. (b) SST anomalies for Jan 2000. (c) SST anomalies for Feb 2000. Contour interval for (b) and (c) is $0.5^{\circ} \mathrm{C}$ and shaded areas denote positive anomalies. Data are from Reynolds optimally interpolated SST. 


\section{Jan-7 Feb mean}

(a)

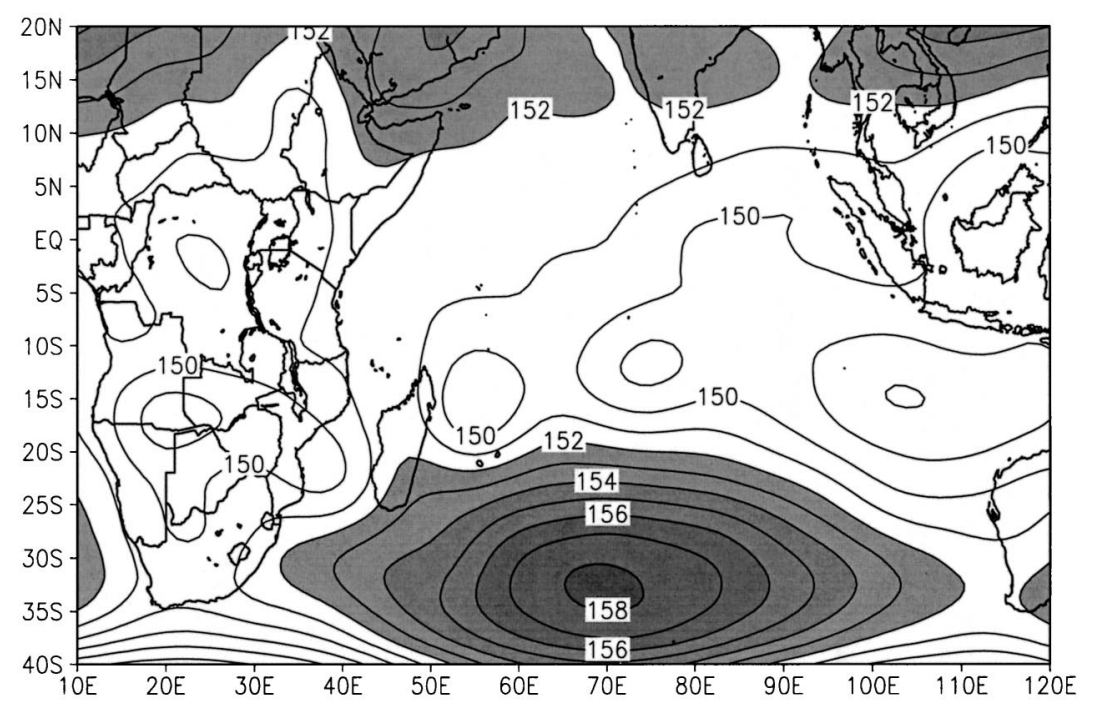

(b)

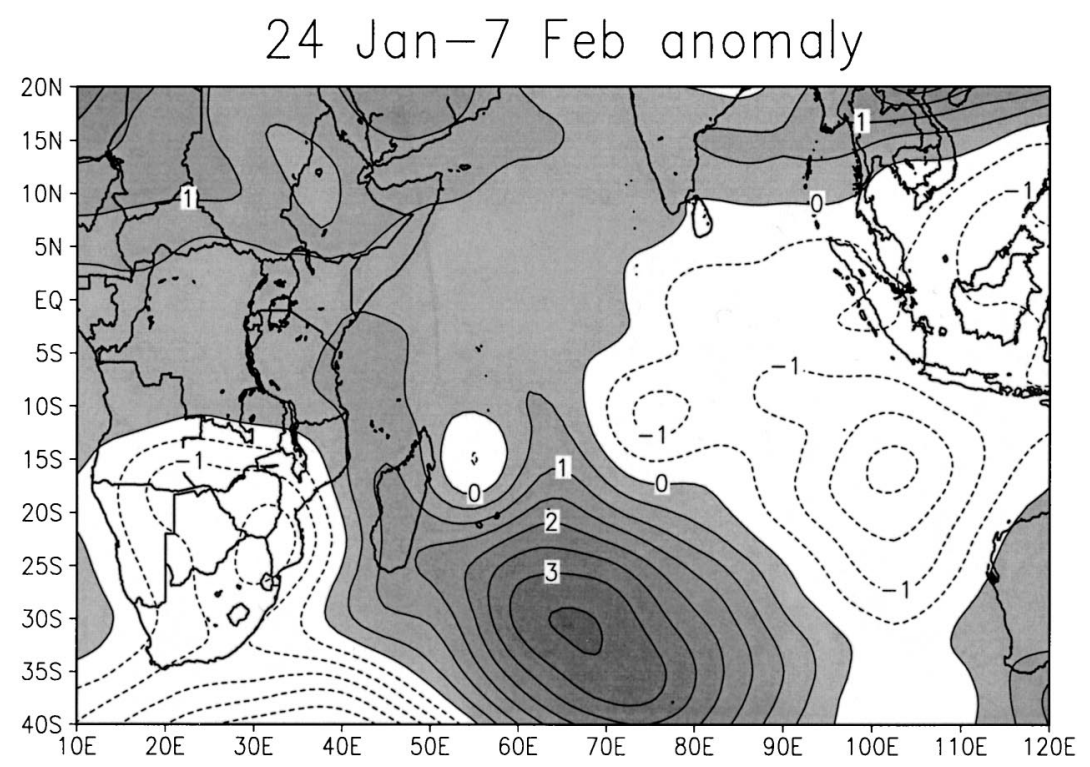

FIG. 10. (a) Mean and (b) anomaly in 850-hPa geopotential height averaged over $24 \mathrm{Jan}-7 \mathrm{Feb}$ from NCEP reanalyses. Contour interval in (a) is 1 dam and in (b) is 0.5 dam. Shading denotes values more than or equal to 152 dam in (a) and positive anomalies in (b).

it accurately. Real-time advisory positions produced by La Réunion were used to verify observations of the location of the system.

Two important statistics are the mean position errors in the along-track (AT) and cross-track (CT) directions. For the UKMO model, the mean AT errors along Eline's track were 17,94 , and $152 \mathrm{~km}$ for the 24-, 48-, and 72$\mathrm{h}$ forecasts, respectively. The La Réunion model forecast had AT mean errors of 70 and $129 \mathrm{~km}$ for the 24- and 48-h forecasts (72-h forecasts not available). Mean CT errors were 76, 118, and $144 \mathrm{~km}$ for the UKMO 24-,
48-, and 72-h forecasts, and 80 and $133 \mathrm{~km}$ for the La Réunion 24- and 48-h forecasts. Regarding direct positional errors, the UKMO means were 146, 276, and $373 \mathrm{~km}$ for the 24-, 48-, and 72-h forecasts, and 116 and $211 \mathrm{~km}$ for the 24- and 48-h La Réunion forecasts. Note that UKMO statistics are computed over the full ocean track of the storm (4-23 February) whereas the La Réunion results are only for 8-21 February (24-h forecast) or 8-19 February (48-h forecast). These operational centers reported that the forecasts generally had a left-of-observed-track and fast bias. This bias was 
(a)

Dec 1999

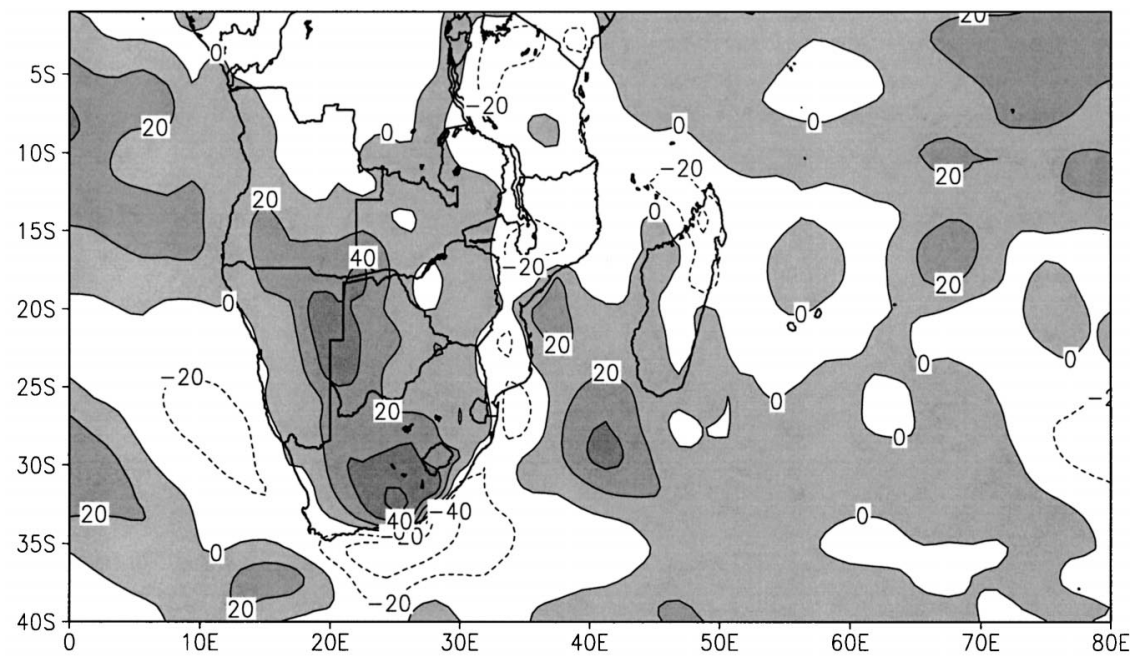

(b)

Jan 2000

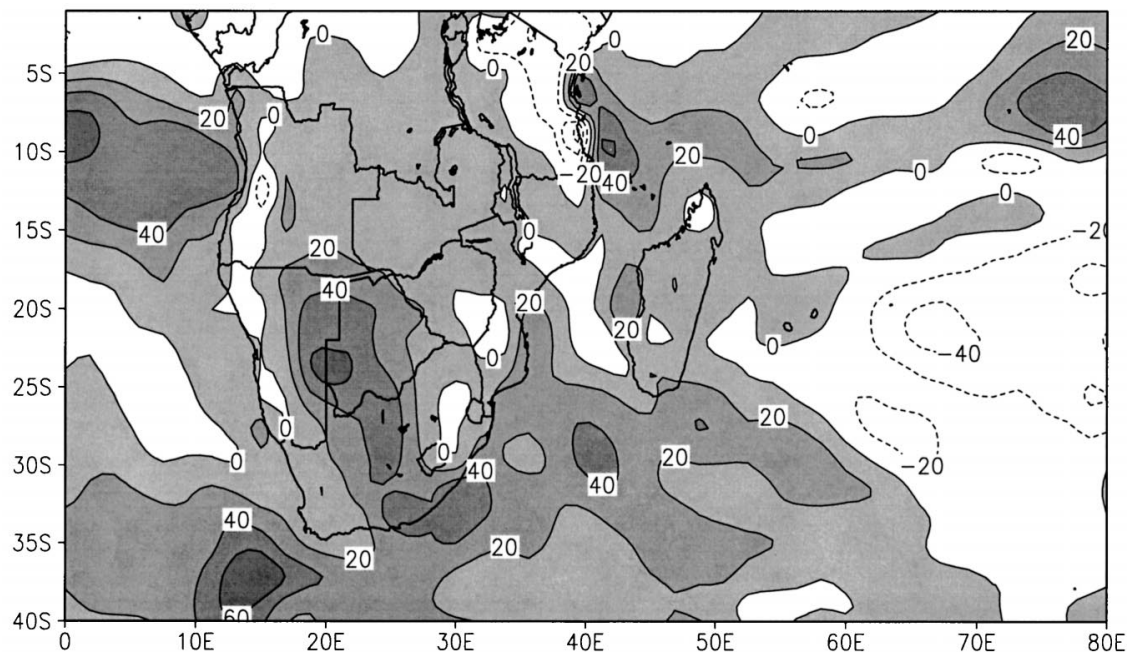

FIG. 11. Latent heat flux anomalies (contour interval of $20 \mathrm{~W} \mathrm{~m}^{-2}$ ) for (a) Dec 1999, (b) Jan 2000, and (c) 11-20 Feb 2000 (the 10 days prior to Eline approaching Mozambique). Positive anomalies are shaded.

larger for $60^{\circ}-70^{\circ} \mathrm{E}$, where the models tended to forecast a track more due west or even west-southwest rather than the observed turn to the north (Fig. 1).

The UKMO errors in forecasting Leon-Eline were about average for SWIO storm forecasts for the previous season, and the model showed skill over CLIPER forecasts (Heming 2001). The latter is a model based on climatology in the application area and persistence. Using the definition of forecast skill as (CLIPER DPE UKMO DPE)/CLIPER DPE $\times 100 \%$, where DPE is the direct positional error between the model and observed center, the skill scores were $23 \%, 36 \%$, and $51 \%$ for the 24-, 48-, and 72-h forecasts. These scores indicate the improvements available from the UKMO NWP model, particularly with increasing lead time.

\section{c. Rainfall forecasts from the South African Weather Bureau}

The above statistics do not include the track after landfall in Mozambique. It is difficult to make assessments of forecast accuracy over the mainland since, with the exception of South Africa (SAWB), the forecasts are not archived by the various countries and verification data are not available. About $4 \mathrm{~h}$ before Eline made landfall (0200 UTC 22 February), the SAWB advised 


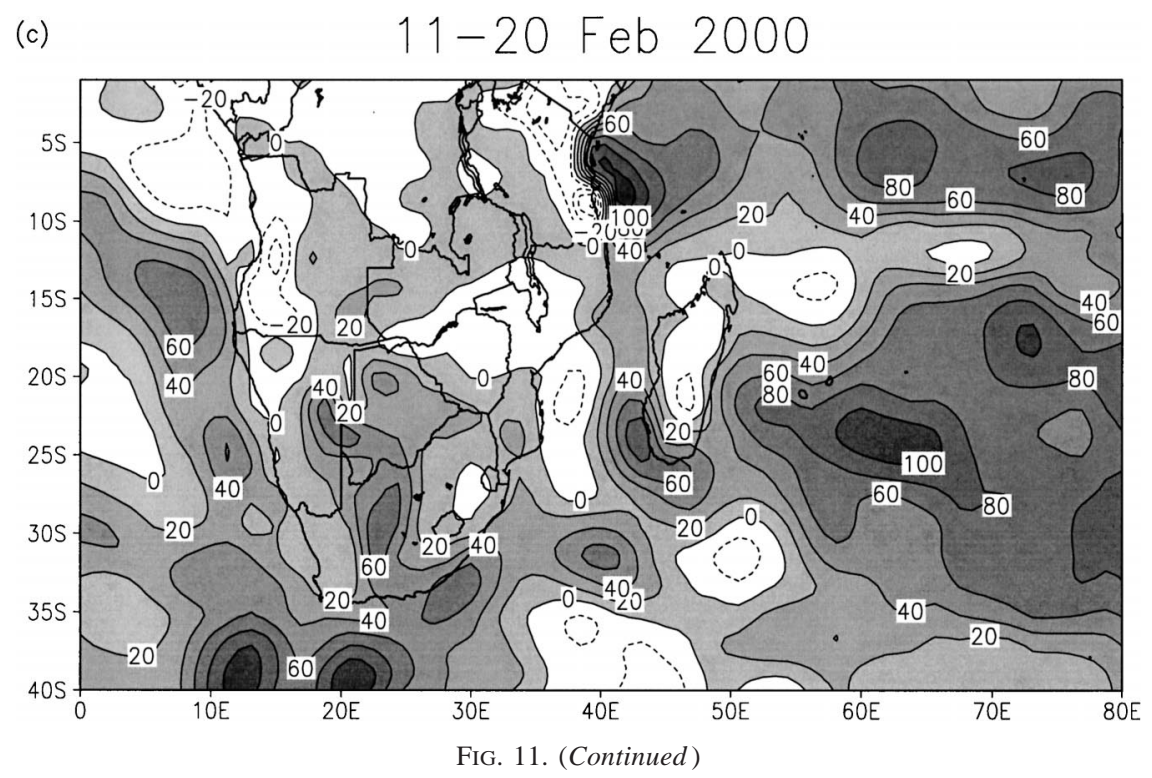

that there was no immediate threat of heavy rain over northeastern South Africa, although heavy rains were possible within a few days. In fact, over $500 \mathrm{~mm}$ fell at some stations during 22-25 February. The 24- and 48-h forecasts for centers in northeastern South Africa were for showers and occasional rain. The 1200 UTC bulletin advised that widespread rain was expected over northeastern South Africa with a few heavy falls over the northern escarpment within the next 12-24 h. At 0200 UTC 23 February, the SAWB issued a warning for heavy rains in the far north of the country and highlighted the fact that ex-Eline was moving farther inland. The warning for heavy rain was extended to northeastern South Africa at 1400 UTC. At 1000 UTC 24 February, a warning for very heavy rain over northeastern South Africa and flooding near rivers and dams was issued with moderate rain likely over the next 2 days.

The 0200 and 0400 UTC 25 February bulletins repeated these warnings and noted that although the storm was weakening over Botswana and rainfall over northeastern South Africa should moderate, heavy rains should still be expected that day. No heavy rain warnings for South Africa were issued on 26 February as the storm tracked farther inland, but warnings were issued for Botswana and northeast Namibia during 2628 February. At 0400 UTC 29 February, the SAWB issued a heavy rain warning for central and southeast Namibia, timely given that this was the wettest day of the entire summer. Whether or not Namibian forecasters issued warnings is unknown; however, the public were able to access SAWB forecasts via the media.

SAWB rainfall forecasts from the Eta model (using the Betts-Miller scheme) for northern South Africa have been compared with observations for February 2000 by Dyson and van Heerden (2001). As a result of Eline and a tropical depression in early February, this region received very heavy rainfall with flooding. The Eta model horizontal resolution is a uniform $0.5^{\circ}$, so it does not capture local vegetation gradients between the Kruger National Park (savanna) and neighboring farms (mainly fruit, sugar, and cattle) and pine or eucalyptus plantations, or orographic details. Orography is well known by local meteorologists to be important for modifying rainfall over much of southern Africa. During the 3 days following Eline's landfall on 22 February, stations near the interior escarpment of northeastern South Africa received rainfall of 400-550 $\mathrm{mm}$ (about 3 times the February mean), whereas the Eta model totals for this time were about $100-150 \mathrm{~mm}$. The model only simulated over $200 \mathrm{~mm}$ in a very small area in the lowlying region near the Mozambique border, and the model-predicted region of heavy rainfall did not extend far enough west into northern South Africa. Such underestimations of heavy rain by the Eta model, particularly near the escarpment, are common; for example, similar errors occurred for the early February 2000 tropical low case (Dyson and van Heerden 2001) and for a previous flooding event in 1996 (De Coning et al. 1998).

Besides limited NWP capability in southern Africa, another serious difficulty facing forecasters is a lack of weather radars and radiosondes, and ongoing reductions in their availability. Only South Africa has an operational radar network for severe weather monitoring (radars in Madagascar and Mozambique had stopped working some time before Eline). There are only four sounding stations along the roughly $3000 \mathrm{~km}$ of coastline in South Africa (Alexander Bay, Cape Town, Port Elizabeth, and Durban), and these now provide soundings only every $24 \mathrm{~h}$ instead of every $12 \mathrm{~h}$. In northern South Africa, there are two stations, Irene $\left(25.7^{\circ} \mathrm{S}, 28.2^{\circ} \mathrm{E}\right)$ and Pietersburg $\left(23.9^{\circ} \mathrm{S}, 29.5^{\circ} \mathrm{E}\right)$, both of which try to make two ascents during summer. In February 2000, only 
Irene did two ascents per day (0000 and 1200 UTC), while only the 0000 UTC ascent was done at Pietersburg. A significant gap exists between Pietersburg and the next station to the north, Harare $\left(18.3^{\circ} \mathrm{S}, 31.1^{\circ} \mathrm{E}\right)$, where at most one sounding per day is made, depending on resources. Data elsewhere in southern Africa are even more problematic, and in fact no radiosondes were released in Mozambique or Namibia for this or subsequent years. This lack of sounding data causes significant difficulties for model verification, reliable data assimilation into operational models like Eta, and forecast accuracy in the region.

\section{Conclusions}

Late summer 2000 was very wet, both in flooded Mozambique and on the arid western side of southern Africa in Namibia. Over southern Namibia, the February and March rainfall were each over two standard deviations above average and JFM 2000 represented by far the wettest season since 1976. About $25 \%$ of this rainfall was due to the passage of ex-TC Eline $2000 \mathrm{~km}$ across southern Africa. Eline was the longest-lived tropical storm observed to date in the region. Generally, TCs in the Mozambique Channel move south and curve southeast into the Indian Ocean, and there is subsidence to the west over southern Africa and dry conditions (Mason and Jury 1997). Only about 5\% of TCs in the southwest Indian Ocean over the last 50 years actually made landfall somewhere along the east coast of southern Africa. Even fewer penetrate to any significant extent into the mainland, because of the $1-1.5-\mathrm{km}$-high interior plateau and relatively dry surface conditions over most of southern Africa. Thus, the evolution of exTC Eline was very unusual.

It has been argued that large-scale precursor synoptic conditions (strong ridge south of the Mozambique Channel, preceding trough over southern Africa, and an easterly steering current at midlevels) promoted the track of Eline. In addition, the seasonal atmospheric circulation and regional SST anomalies associated with the JFM 2000 strengthening of the protracted 1998-2001 La Niña episode produced very favorable conditions for this event. This La Niña induced very wet conditions over southern Africa prior to the event, leading to favorable soil moisture and land surface conditions for westward penetration of Eline and ongoing convection.

Southern Africa is prone to devastating flood and drought episodes and pronounced climate variability on a range of scales, the coefficient of annual rainfall variation being greatest in southern Namibia. Because of this variability, it is necessary for local weather forecasters to be cognizant of seasonal forecasts and evolving climate anomalies. These anomalies can significantly impact extreme event frequency and characteristics in southern Africa by modifying the background atmospheric and ocean environment. Local forecasters should be aware of the precursor synoptic conditions for TC landfall, the previous few months' rainfall, and the current state of the vegetation (and by inference, soil moisture), as well as regional SST anomalies, the orientation of the $28^{\circ} \mathrm{C}$ isotherm, and ENSO phase. Vitart et al. (2003) show that La Niña conditions may increase the risk of TC landfall in Mozambique by enhancing the westward steering flow and that this risk is increased further if local SST anomalies are warm. Given that La Niña state and regional circulation, SST, and rainfall anomalies are available in near real time over the internet, local forecasters across the region could have been in a heightened state of alertness by January 2000. Unfortunately, since TCs rarely penetrate inland, such alertness would have been unlikely in most southern African forecast offices.

Although not feasible for southern African operational agencies under current funding, the prototype ECMWF coupled model experiments (Vitart et al. 2003) suggest that improved seasonal skill in forecasting the interannual variability in TC tracks and frequency could be used to predict the risk of Mozambican landfall. This may be something that could be implemented by forecast offices with more resources, for example, RSMC La Réunion. For financially constrained agencies in southern Africa, developing simple CLIPER-type models (such as those in use in Mauritius) that incorporate regional and ENSO conditions available on the Internet may be more feasible. Developing improved forecasting in southern Africa is hampered by a lack of human and financial resources, limiting or, in many cases, precluding radiosonde and surface measurements as well as running NWP and other dynamical models. These forecasting challenges are particularly pronounced over $\mathrm{Na}$ mibia, where the inherent atmospheric conditions add to the difficulties. These challenges motivate strongly for innovative solutions, including developing better partnerships with universities, industry, and international operational agencies.

Acknowledgments. Dr. Beenay Pathack, Mauritius Meteorological Services, provided Fig. 1 as well as information about local forecasts and observations during Eline. Anne-Claire Fontan, Méteo France, supplied statistics concerning La Réunion forecasts, and Mathieu Rouault provided TRMM SST data. Wendy Nkuna and Tracey Gill, South African Weather Service (SAWS), provided information about forecasts issued by the then South African Weather Bureau. We thank Dr. Warren Tennant, SAWS, for helpful discussions. Andrew Singleton produced some of the figures. Partial funding from the South African government Innovation Fund is gratefully acknowledged. We thank two anonymous reviewers for their comments, which helped to improve the paper.

\section{REFERENCES}

Anyamba, A., C. J. Tucker, and R. Mahoney, 2002: From El Niño to La Niña: Vegetation response patterns over east and southern Africa during the 1997-2000 period. J. Climate, 15, 3096-3103. 
De Coning, E., G. S. Forbes, and E. P. Poolman, 1998: Heavy precipitation and flooding on 12-14 February 1996 over the summer rainfall regions of South Africa: Synoptic and isentropic analyses. Natl. Wea. Digest, 22, 25-36.

Diab, R. D., R. A. Preston-Whyte, and R. Washington, 1991: Distribution of rainfall by synoptic type over Natal, South Africa. Int. J. Climatol., 11, 877-888.

Dyson, L. L., and J. van Heerden, 2001: The heavy rainfall and floods over the northeastern Interior of South Africa during February 2000. S. Afr. J. Sci., 97, 80-86.

Heming, J. T., 1994: Keeping an eye on the hurricane-Verification of tropical cyclone forecast tracks at the Met Office. NWP Gazette, 1 (2), 3-8.

- 2001: Summary of tropical cyclone activity and forecasts in the 1999-2000 Southern Hemisphere season. U.K. Met. Office Forecasting Research Tech. Rep. 342, 14 pp.

Jury, M. R., 1993: A preliminary study of climatological associations and characteristics of tropical cyclones in the SW Indian Ocean. Meteor. Atmos. Phys., 51, 101-115.

_ ability over the tropical southwest Indian Ocean. Meteor. Atmos. Phys., 47, 37-48.

$\_,-$, and B. Parker, 1999: Climatic determinants and statistical prediction of tropical cyclone days in the southwest Indian Ocean. J. Climate, 12, 3369-3372.

Kalnay, E., and Coauthors, 1996: The NCEP/NCAR 40-Year Reanalysis Project. Bull. Amer. Meteor. Soc., 77, 437-471.

Kummerow, C., C. W. Barnes, T. Kozu, J. Shiue, and J. Simpson, 1998: The Tropical Rainfall Measuring Mission (TRMM) sensor package. J. Atmos. Oceanic Technol., 15, 809-817.
Mason, S. J., and M. R. Jury, 1997: Climatic variability and change over southern Africa: A reflection on underlying processes. Prog. Phys. Geogr., 21, 23-50.

Olivier, J., 1993: Flood producing weather systems: Tropical cyclones. Flood Risk Reduction Measures, W. J. R. Alexander, Ed., University of Pretoria, 23-34.

Reason, C. J. C., R. J. Allan, J. A. Lindesay, and T. J. Ansell, 2000: ENSO and climatic signals across the Indian Ocean basin in the global context. Part I: Interannual composite patterns. Int. J. Climatol., 20, 1285-1327.

Reynolds, R. W., and T. M. Smith, 1994: Improved global sea surface temperature analyses using optimal interpolation. J. Climate, 7, 929-948.

RSMC La Réunion, 2002: La Réunion Tropical Cyclone Centre. Information brochure, Météo France, La Réunion, 12 pp.

Stammer, D., and Coauthors, 2003: Volume, heat and freshwater transports of the global ocean circulation 1993-2000, estimated from a general circulation model constrained by World Ocean Circulation Experiment (WOCE) data. J. Geophys. Res., 108, 3007, doi:10.1029/2001JC001115.

van Heerden, J., and J. J. Taljaard, 1988: Africa and surrounding waters. Meteorology of the Southern Hemisphere, D. J. Karoly and D. G. Vincent, Eds., Amer. Meteor. Soc., 141-174.

Vitart, F., D. Anderson, and T. Stockdale, 2003: Seasonal forecasting of tropical cyclone landfall over Mozambique. J. Climate, 16, 3932-3945.

Xie, S.-P., H. Annamalai, F. A. Schott, and J. P. McCreary, 2002: Structure and mechanisms of south Indian Ocean climate variability. J. Climate, 15, 864-878. 